\title{
電子機器冷却用熱コネクタの設計手法の検討
}

\author{
林 知生 ${ }^{* 1}$, 近藤 義広*1, 豊田 浩之*1, 佐藤 重匡 ${ }^{* 2}$, 椿 繁裕 ${ }^{* 2}$
}

\section{Design method of thermal connector for electronic equipment cooling}

\author{
Tomoo HAYASHI ${ }^{*}$, Yoshihiro KONDO ${ }^{* 1}$, Hiroyuki TOYODA ${ }^{* 1}$, Shigemasa SATO*2 \\ and Shigeyasu TSUBAKI ${ }^{* 2}$ \\ ${ }^{* 1}$ Center for Technology Innovation - Mechanical Engineering, Research and Development Group, Hitachi, Ltd., \\ 832-2 Horiguchi, Hitachinaka-shi, Ibaraki 312-0034, Japan \\ ${ }^{* 2}$ Information \& Communication Technology Business Division, Hitachi, Ltd., \\ 1 Horiyamashita, Hadano-shi, Kanagawa 259-1392, Japan
}

Received: 26 December 2016; Revised: 28 February 2017; Accepted: 1 May 2017

\begin{abstract}
We have developed the evaluation method for two performance factors to design the thermal connector: Insertion force of thermal grease and thermal conductance. The thermal connector was comprised of a thermal plug and a thermal socket, and the thermal grease which was filled into the gap between the thermal plug and the thermal socket connected the thermal plug and the thermal socket thermally. Firstly, the insertion force was theoretically calculated using the Bingham plastic model for rheology characteristics of the thermal grease and the slip model on the surfaces of the thermal plug and the thermal socket. The calculated results were in good agreement with the experimental results. Secondly, the experimental results of the thermal conductance between the thermal plug and the thermal sockets at the first connection to the 20 times connection were -1 to +26 percent greater than the theoretical value. The reason why some experimental results exceed the theoretical results is the eccentricity between the thermal plug and the thermal socket. In addition, the filling status of the thermal grease in the gap was visualized by ultrasonic testing. The results after the 20 times connections showed there were some voids in the thermal grease and the area of voids was 4 percent of the heat transfer area. Therefore, the thermal conductance was mostly not influenced by the voids. Finally, it was found that the proposed methods to predict the insertion force and thermal conductance were reasonable.
\end{abstract}

Key words : Thermal connector, Thermal grease, Thermal conductance, Pressure drop, Bingham plastic model, Slip

\section{1. 緒言}

ビッグデータ分析に代表されるように，情報処理量が飛躍的に増大している今日にあっては，サーバ機器の消 費電力量は年々増加している. サーバ機器の年間消費電力量は, 2050 年には 2005 年の 3 倍に達すると予測され ている（グリーン IT 推進協議会 調査分析委員会，2013）。とりわけ，ブレードサーバに代表されるボリュームク ラスと言われる比較的安価なサーバ機器の消費電力量は，サーバ機器全体の消費電力量の 9 割以上を占めるとさ れており，その消費電力を削減することで環境負荷を低減することが期待されている.

ブレードサーバは，シャーシに任意の台数のサーバモジュールを搭載して使用するサーバであり，機器構成が 柔軟に変更でき，咒長性の確保が容易であって運用管理がしやすいため，データセンタ等で広く使用されている

（實方他，2008）。ただし，ブレードサーバの情報処理能力の向上が進んだ結果，サーバモジュール内は高密度実 装状態となっており，CPU（Central Processing Unit）を冷却するための冷却風の圧力損失が増加し，冷却効率が低 下寸る課題がある，そのため，ブレードサーバの消費電力に占めるファン電力の割合が高くなっており，冷却効

No.16-00580 [DOI:10.1299/transjsme.16-00580], J-STAGE Advance Publication date: 18 May, 2017

*1 正員, (株) 日立製作所 研究開発グループ 機械イノベーションセンタ（广312-0034 茨城県ひたちなか市堀口 832-2)

*2（株）日立製作所 ICT 事業統括本部（†259-1392＼cjkstart神奈川県秦野市堀山下 1)

E-mail of corresponding author: tomo.hayashi.rt@hitachi.com 
率を上げてファン電力を低減することは, ブレードサーバの消費電力削減のための必須課題となっている.

ファン電力の削減のために, CPU の排熱を熱輸送デバイスでサーバモジュール外輸送し, サーモジュール外 に設置したラジエータ等で空気へ放熱する冷却方式が検討されている(新他, 2004) (近藤, 2010) (藤本他, 2014). このような冷却方式を採用した場合, サーバモジュールをシャーシに取り付ける際に, 熱輸送デバイスの接続が 必要となる. 従来の研究では, シャットオフバルブ付きのカップリングを用いて熱輸送デバイスの接続を行って いる（新他，2004）が，着脱の際に液漏孔が起こった場合，電子部品を故障に至らしめる可能性があるため，高 い信頼性が求められるサーバ機器に採用することが難しい.

このような熱輸送デバイスの接続の課題に対して，著者らは，熱伝導グリースを用いた新しい熱コネクタを開 発した（林他，2010）。この開発成果は，国立研究開発法人新エネルギー・産業技術総合開発機構（NEDO）の委 託業務の結果得られたものである. この熱コネクタでは, 接続する両側をそれぞれソケット (蔀) とプラグ (凸 部）とし，プラグをソケットに挿入した後で，その隙間に熱伝導グリースを充填することでソケットープラグ間 の熱抵抗を低減する.熱コネクタの伝熱性能をより高くするためには, 1熱伝導グリースの熱伝導率が高いこと, (2)プラグとソケットの隙間が小さいこと, (3)熱伝導グリースが十分に充填されていること, の 3 要件が必要とな る.

熱伝導グリースは, シリコーンオイル等の基油に, 熱伝導率の高い酸化亜鉛, 窒化ホウ素, 窒化アルミニウム 等のフィラーを配合して作られる（山田他，2000）。そのため, 一般には, 熱伝導性の良いものほどフィラーの配 合割合が高く, 流動性が低い傾向がある. また，プラグとソケットの隙間が小さいほど伝熱性能が良くなるが， その一方で, 熱伝導グリースを充填する際に必要な力（以下, グリース充填力と呼ぶ） は大きくなる. そのため, 熱コネクタ設計の際には, 熱伝導グリースを充填するための力と伝熱性能の仕様に適合するように, 寸法諸元の 決定や熱伝導グリースの選定を行う必要があるが，その手法は確立されていない. また，従来，熱伝導グリース の流動挙動に関しては, 放熱面の熱膨張による反り変形が原因となって熱伝導グリースが叙布面から流出する, いわゆるポンピングアウト現象に関する検討（藤本，2013）があるものの, 流動挙動を流体力学的に評価した例 はない。

そこで，本研究では，ソケットとプラグの間の隙間に熱伝導グリースを充填することで両者を熱的に接続する 方式の熱コネクタの設計手法を確立することを目的として, グリース充填力と伝熱性能の予測方法を検討した. グリース充填力に関しては, 熱伝導グリースの非ニュートン性を考慮して, 隙間部流動時の圧力損失の理論值を 導出し, 実測結果と比較検討した。また, 伝熱性能に関しては, 熱伝導グリースの充填動作を 20 回繰り返し実施 してその都度の熱コンダクタンスを測定し, 理論值と比較検討した. さらに, 超音波試験による可視化を行い, 熱コネクタ内の熱伝導グリースの充填状況を確認した.

\section{2. 主な記号}

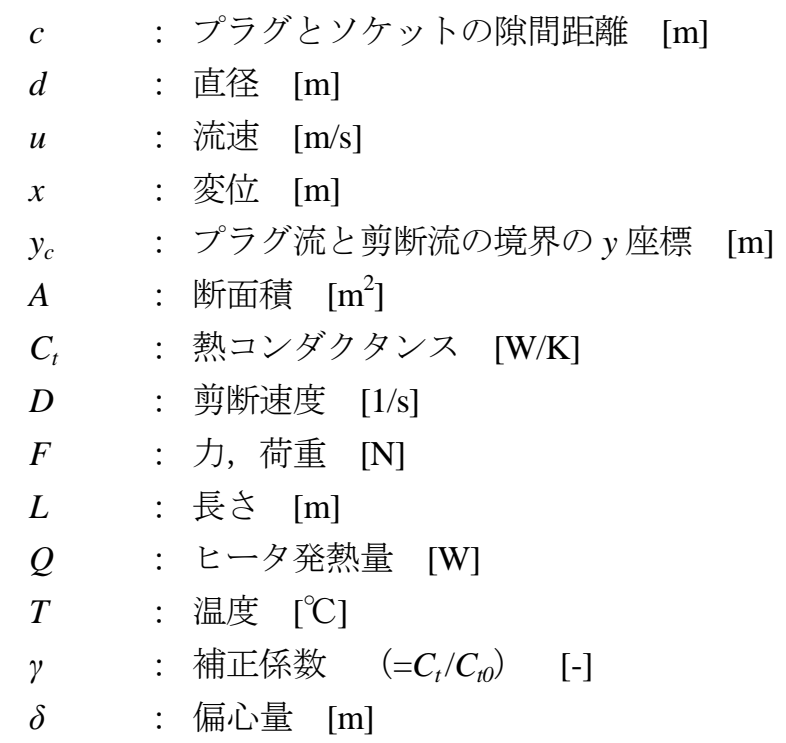



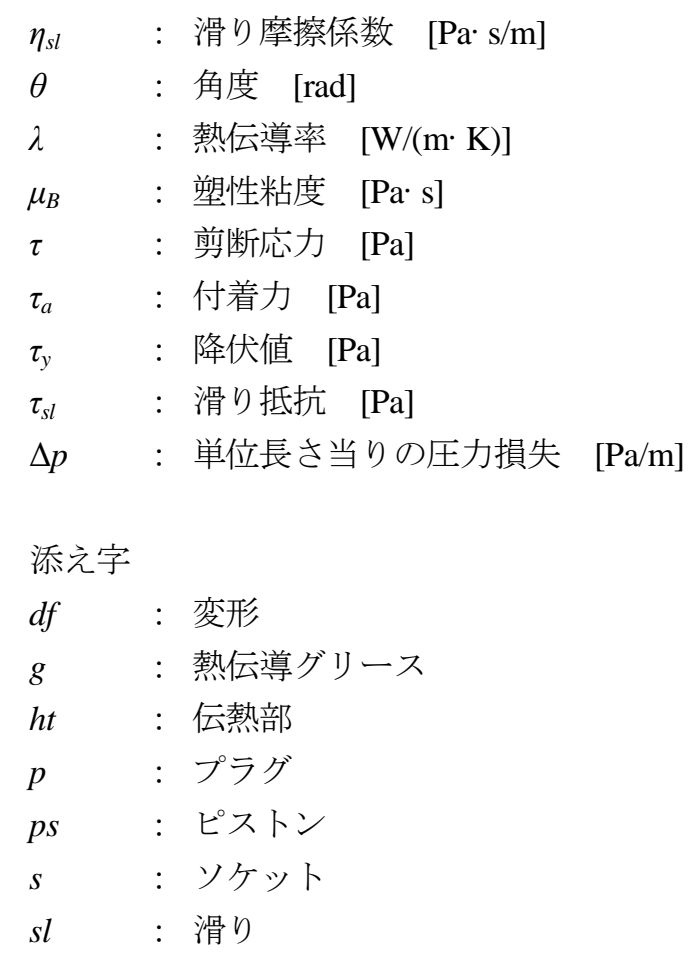

Thermal connector

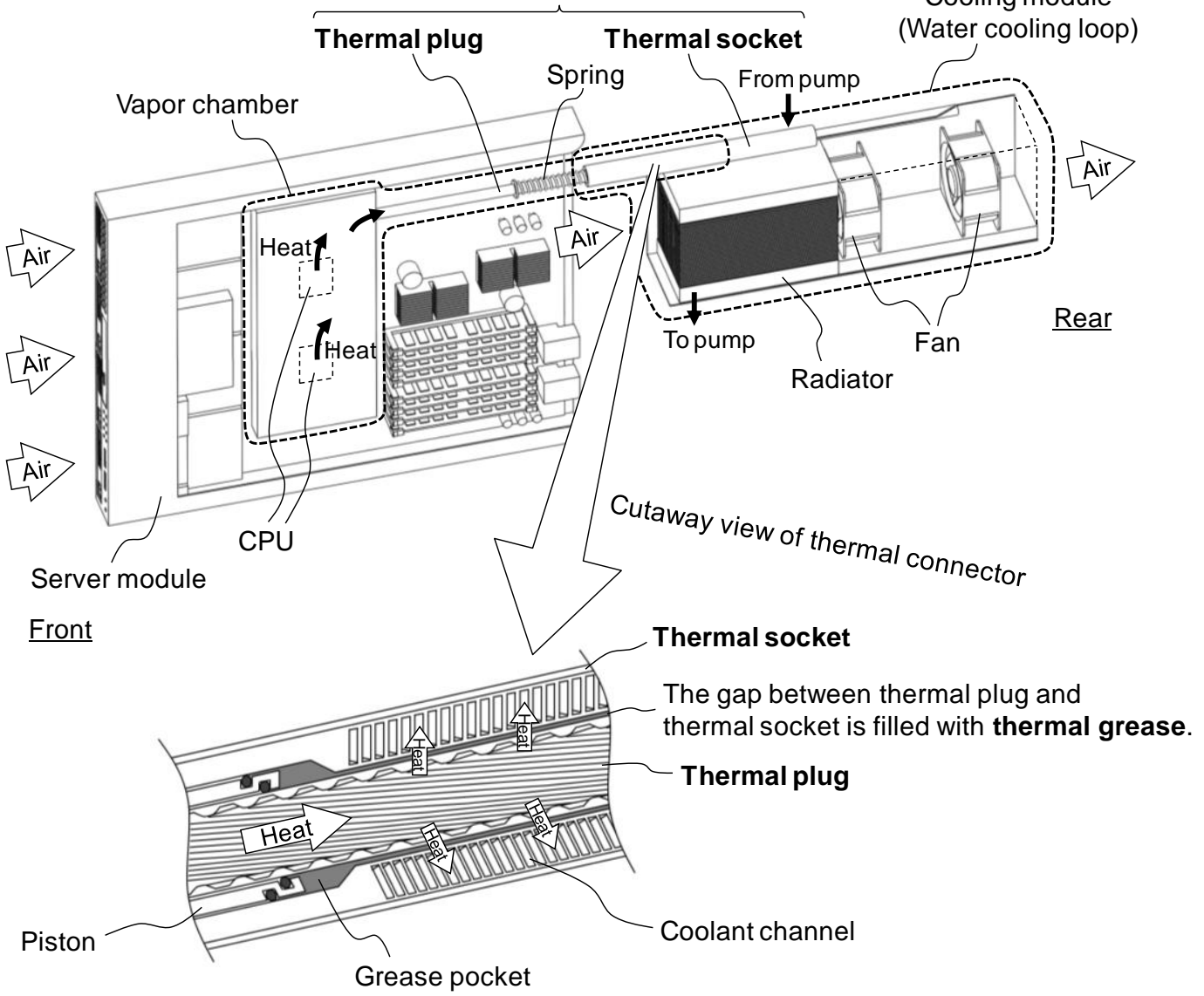

Fig. 1 The arrangement of cooling system using thermal connector for server module cooling. The thermal connector transfer exhausted heat from vapor chamber to water cooling loop. 


\section{3. 熱コネクタの構造と設計パラメータ}

図 1 に，熱コネクタを用いた冷却システムの一例と，熱コネクタの内部構造を図示する. この冷却システムで は, サーバモジュール内の CPU の排熱を熱輸送デバイスによって冷却モジュール内のラジエーター輸送し, 冷却 ファンによって駆動される空気へ放熱している．熱輸送デバイスは，サーバモジュール内のベーパチャンバと冷 却モジュール内の水冷ループに分割され，それらを熱コネクタによって接続する．ベーパチャンバの凝縮部が熱 コネクタのプラグに相当し，水冷ループの受熱部がソケットに相当する.

図 2 に，熱コネクタの接続動作を図示寸る。サーバモジュールをシャーシに取り付ける際，プラグがソケット に挿入される (図 2 (a)). その後, ソケットのグリース溜めに予め貯留していた熱伝導グリースをピストンによ って，プラグとソケットの隙間に充填する（図 2 (b))。ピストンは，サーバモジュールに取り付けたばねの復元 力によって押される. このときのグリース充填力の計算方法を, 以下で検討する.

図 3 に, 熱コネクタに熱伝導グリースを充填する際の模式図を示寸.グリース充填力 $F[\mathrm{~N}]$ は, 以下の式で表わ される.

$$
F=A_{p s} L_{g} \Delta p
$$

ここで, $A_{p s}$ はピストンの断面積 $\left[\mathrm{m}^{2}\right], L_{g}$ は充填しているグリース層の長さ $[\mathrm{m}], \Delta p$ は隙間部を流れる熱伝導グリ 一スの単位長さ当りの圧力損失 $[\mathrm{Pa} / \mathrm{m}]$ である．実際には，隙間部の圧力損失に加えて，グリース溜めなどの隙間 部以外でも圧力損失が発生するが，それらは隙間部の圧力損失に比べて十分に小さいと考えられるため，無視で きる.

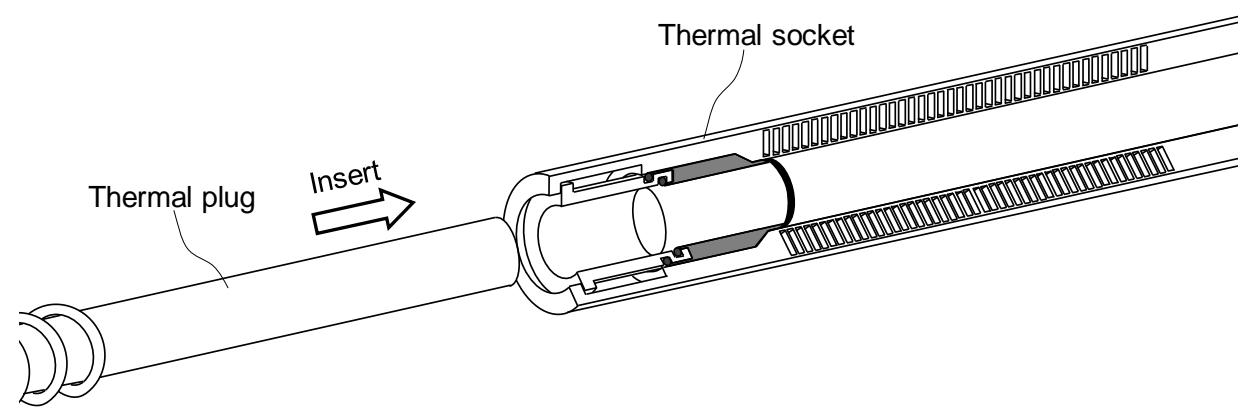

(a) Thermal plug insertion to thermal socket.

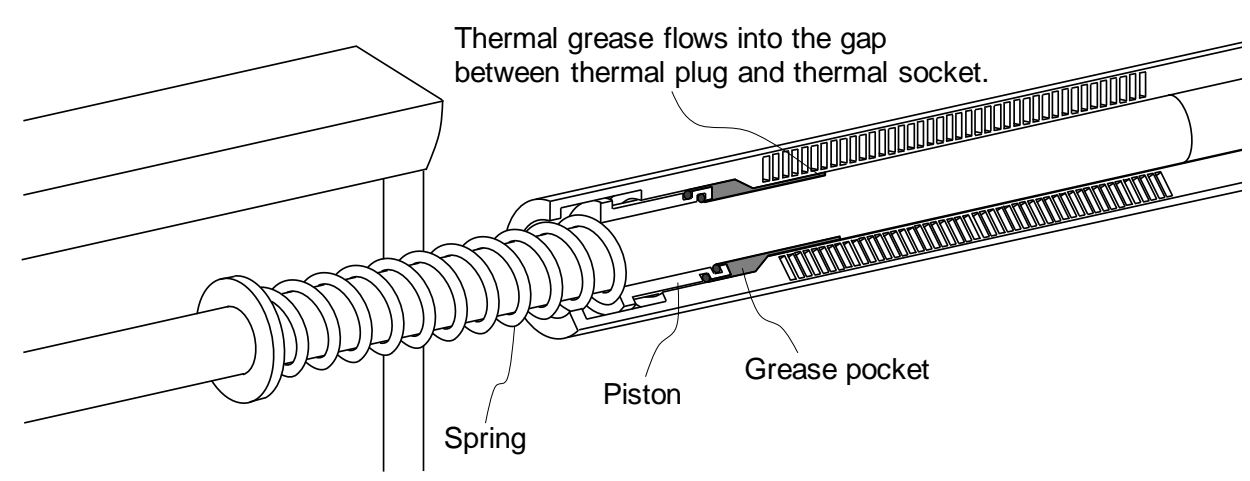

(b) Thermal grease filling into the gap.

Fig. 2 Schematic of insertion process. 


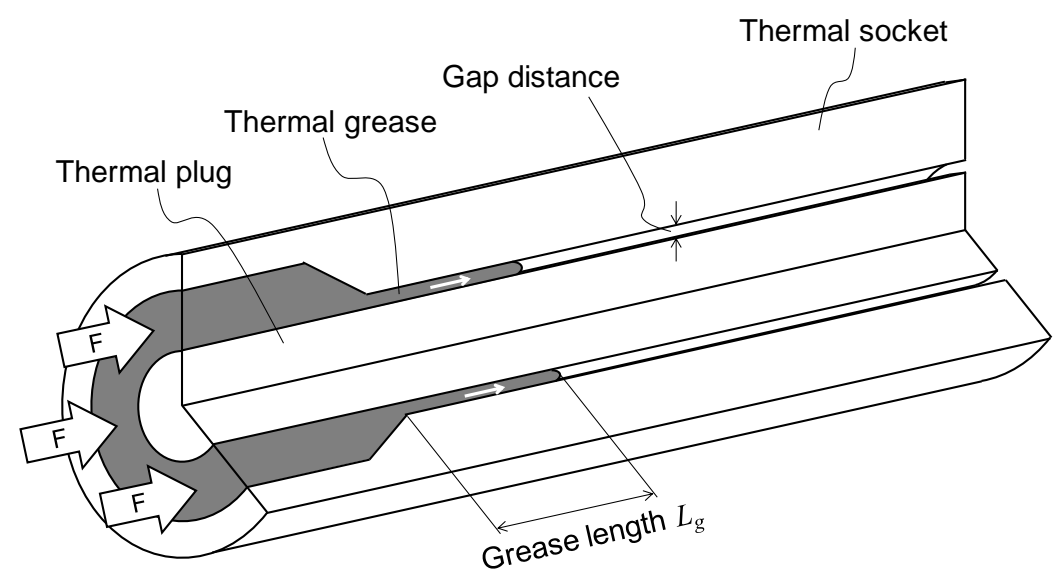

Fig. 3 Schematic of grease filling process. In this process, the grease insertion force is needed for the pressure drop of the thermal grease flows into the gap between thermal plug and thermal socket.

式（1）からわかるように，グリース充填力は，グリース層の長さと隙間部の圧力損失に比例して大きくなる. また，隙間部の圧力損失は，隙間距離が小さいほど大きくなり，熱伝導グリースの粘度が高いほど大きくなると 考えられる，一方，熱コネクタの伝熱性能は，グリース層の長さが長いほど高くなり，隙間距離が小さいほど高 くなり，熱伝導グリースの熱伝導率が高いほど高くなる. 以上の性質を表 1 にまとめて示す. グリース充填力と 伝熱性能はトレードオフの関係にあるので，設計パラメータ（グリース層の長さ，隙間距離，熱伝導グリースの 性質）を適切に設定することが必要となる.

本論では, 4 章で上記の設計パラメータからグリースの圧力損失を予測する方法, 5 章で伝熱性能を予測する方 法を検討した. 加えて 5 章で, 熱コネクタの抜き差しを繰り返し行った際の, 熱伝導グリースの充填状態を確認 した.

Table 1 Influence of design parameters on insertion force of thermal grease and thermal conductance.

\begin{tabular}{l|c|c}
\hline \multicolumn{1}{c|}{ Design parameter } & $\begin{array}{c}\text { Influence on insertion } \\
\text { force }\end{array}$ & $\begin{array}{c}\text { Influence on heat } \\
\text { transfer performance }\end{array}$ \\
\hline \hline Increase of gap between thermal plug and thermal socket & Down & Down \\
\hline Increase of grease length & $\mathrm{Up}$ & $\mathrm{Up}$ \\
\hline Increase of thermal conductivity of grease & $\mathrm{Up}$ & $\mathrm{Up}$ \\
\hline
\end{tabular}

\section{4. グリース圧カ損失の予測方法}

\section{$4 \cdot 1$ 熱伝導グリースの流動特性}

隙間部を流れる熱伝導グリースの圧力損失の特性を明らかにするために，まず，粘性測定装置を用いて熱伝導 グリースの流動特性を測定した。供試グリースには，電子機器の冷却において使用実績がある 3 種類の市販の熱 伝導グリース（グリース A， B，C と呼ぶ）を用いた。供試グリースは，いずれも，シリコーン油に金属酸化物

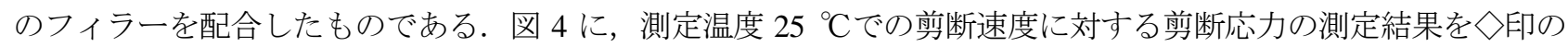
プロットで示す。一般に，グリースは剪断速度と剪断応力が正比例の関係にならない非ニュートン流体の性質を 示すことが知られており（日本機械学会, 1979), 図 4 より, 供試グリースも非ニュートン流体の性質を示すこと が確認できる.ここで, 剪断速度 $D[1 / \mathrm{s}]$ と剪断応力 $\tau$ [Pa]の関係を表わすレオロジー方程式を導入する.レオロ ジ一方程式は, $4 \cdot 3$ 節で記述する圧力損失の理論值を算出するために用いる. ここでは, レオロジー方程式が以 下の式となるビンガム流体と仮定して, 供試グリースの流動特性をモデル化した. 


$$
\left.\begin{array}{ll}
\mu_{B}|D|=\tau-\tau_{y} & \left(\tau \geq \tau_{y}\right) \\
D=0 & \left(\tau<\tau_{y}\right)
\end{array}\right\}
$$

ここで， $\tau_{y}$ は降伏值 $[\mathrm{Pa}], \mu_{B}$ は塑性粘度 $[\mathrm{Pa} \cdot \mathrm{s}]$ であり，ビンガム定数と呼ばれる物性值である. 表 2 に，測定結果 から求めた $\tau_{y}, \mu_{B}$ を示す. 図 4 に, 式 (2) より求めた剪断応力特性を破線で示す. 図より, プロットと破線は比 較的よく一致していることがわかる。この結果から, 供試グリースをビンガム流体として扱うことの妥当性が確 認された.

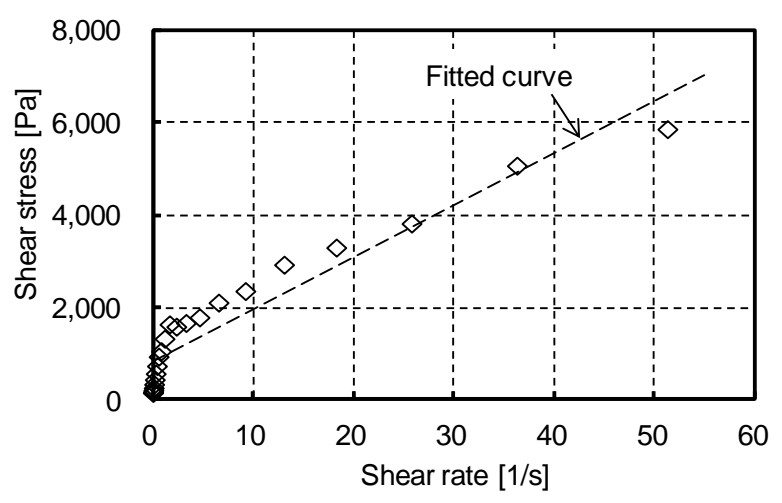

(a) Grease A

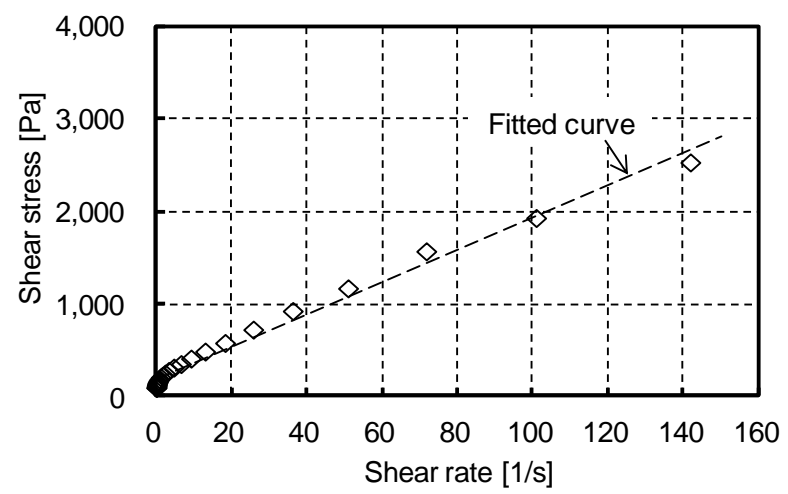

(c) Grease C

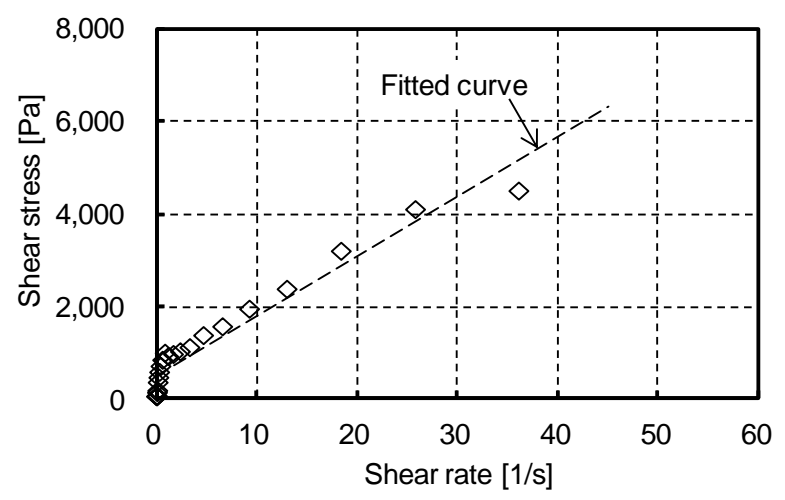

(b) Grease B

Fig. 4 The rheogram of the greases. The dashed lines of each figures are the fitted curves which were generated using rheology equation of the Bingham plastic model.

Table 2 Bingham constants of the test greases.

\begin{tabular}{c|c|c}
\hline Grease & $\tau_{y}[\mathrm{~Pa}]$ & $\mu_{B}[\mathrm{~Pa} \cdot \mathrm{s}]$ \\
\hline \hline Grease A & 808 & 113 \\
\hline Grease B & 490 & 130 \\
\hline Grease C & 187 & 17.5 \\
\hline
\end{tabular}




\section{$4 \cdot 2$ 圧力損失測定実験}

図 5 に，実験装置概略図を示す．実験装置は，ソケットを模擬したパイプ，プラグを模擬してパイプの中に配 置した軸，および，ピストンより構成した，プラグとピストンは SUS 製であり，ソケットは，グリース B の実 験では SUS 製とし，グリース A と C の実験ではグリースの流動を目視確認するためにガラス製とした. パイプ

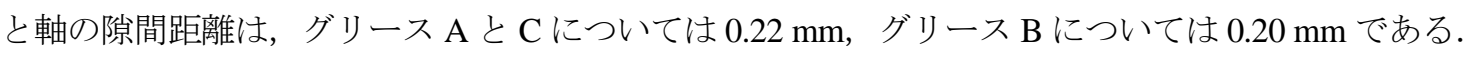

実験の測定開始前に，軸の上部に熱伝導グリースを保持した状態にする．次に，ピストンを一定の速度で押し 下げながらピストンに掛かる荷重を測定する。このときのピストンの変位 $x_{p s}[\mathrm{~m}]$ と荷重 $F_{p s}[\mathrm{~N}]$ から, 以下の式を 用いてグリース層の単位長さ当りの圧力損失 $\Delta p$ を求めることができる.

$$
\Delta p=\frac{A_{g}}{A_{p s}^{2}} \frac{\Delta F_{p s}}{\Delta x_{p s}}
$$

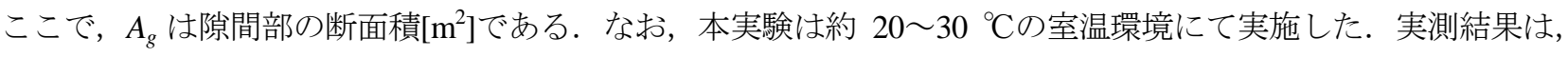
理論值とあわせて次節にて説明する。
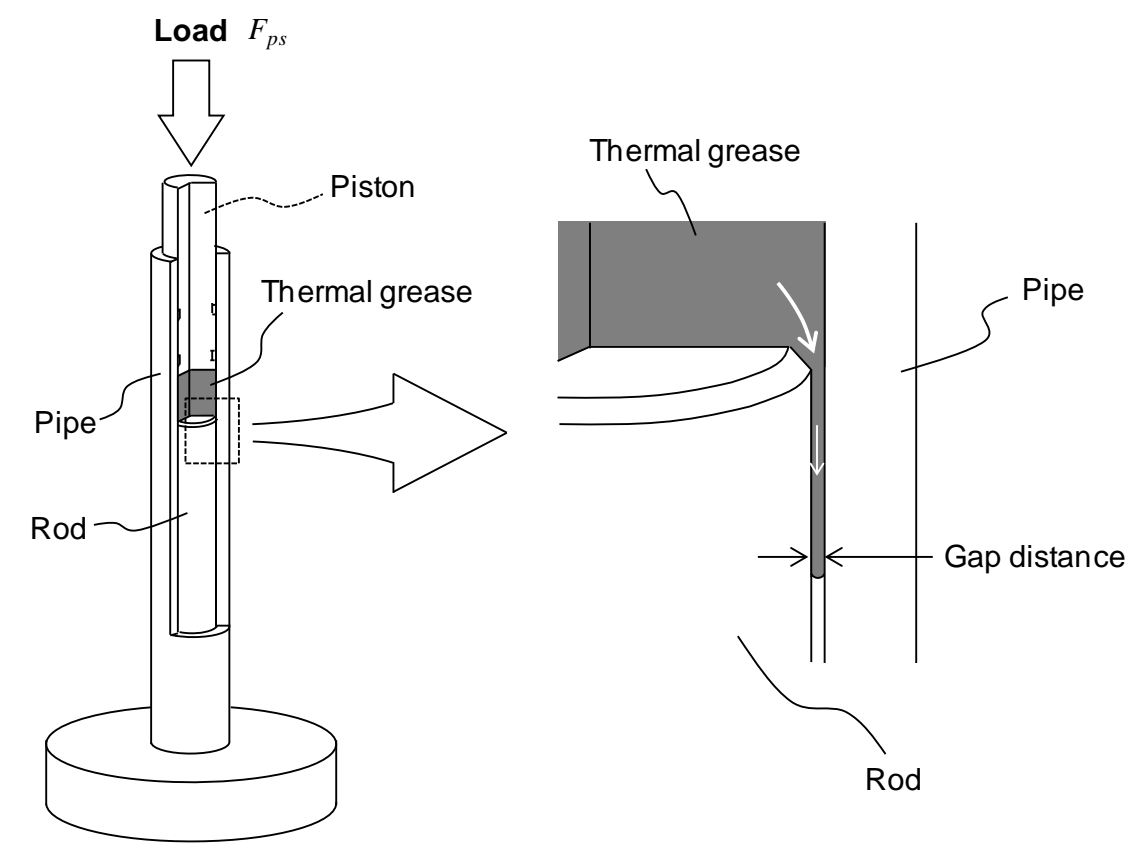

Fig. 5 Experimental apparatus to measure pressure drop of thermal grease flow in the gap. 


\section{$4 \cdot 3$ 熱伝導グリースの圧力損失のモデル化}

プラグの直径に対して隙間距離が十分に小さいため, 熱伝導グリースの隙間部の流れは，近似的に，図 6 に示 すような平行二平板間流れと見なすことができる，このとき，熱伝導グリースはビンガム流体であるため，流路 の中心に流速分布のないプラグ流の領域をもつ流れ場となる．壁面での滑りなしの条件を適用すると，熱伝導グ リースの流速 $u_{d f}[\mathrm{~m} / \mathrm{s}]$ は, $4 \cdot 1$ 節の表 2 に示した供試グリースのビンガム定数を用いて以下の式で表わされる.

$$
\begin{array}{ll}
u_{d f}= \begin{cases}\frac{\Delta p}{2 \mu_{B}}\left(\frac{c}{2}-y_{c}\right)^{2} & \left(0 \leq y \leq y_{c}\right) \\
\frac{\Delta p}{2 \mu_{B}}\left\{\left(\frac{c}{2}-y_{c}\right)^{2}-\left(y-y_{c}\right)^{2}\right\} & \left(y_{c}<y \leq \frac{c}{2}\right)\end{cases} \\
y_{c}=\frac{\tau_{y}}{\Delta p}
\end{array}
$$

ここで, $c$ は隙間距離 $[\mathrm{m}], y_{c}$ はプラグ流と剪断流の境界の $y$ 座標 $[\mathrm{m}]$ である. 区間 $y=0 \sim c / 2$ での式 (4) の積分 平均を取ると, 熱伝導グリースの平均流速 $\bar{u}_{d f}[\mathrm{~m} / \mathrm{s}]$ は, 以下の式で求めることができる.

$$
\bar{u}_{d f}=\frac{\Delta p}{3 \mu_{B}}\left(1+\frac{y_{c}}{c}\right)\left(\frac{c}{2}-y_{c}\right)^{2}
$$

図 7 に，熱伝導グリースの平均流速に対する圧力損失を，実測值と理論值を比較して示す．図 7 で，৩印のプ ロットは前節で述べた実験による実測值, 破線は式（6）による滑りなしの条件での理論值である.いずれの供試 グリースにおいても, 実測值は理論值より低い值となった. 特筆すべきなのは, グリース Cの低速条件 $(0.9 \mathrm{~mm} / \mathrm{s}$ と $1.7 \mathrm{~mm} / \mathrm{s}$ ) では実測值は理論值の 80 90\%の值であって, 差が比較的小さいのに対して, その他の条件では実 測值は理論值の 50 \%程度の值であって, 差が大きい. グリース C の低速条件以外の条件は, 言い換えると, 圧 力損失の大きな条件であり，このように，圧力損失が大きな条件において理論值よりも実測值が小さくなってい る原因として，壁面においてグリースの滑りが発生していることが考えられる．よって，以下では，壁面での滑 りを考慮したモデルを考える.

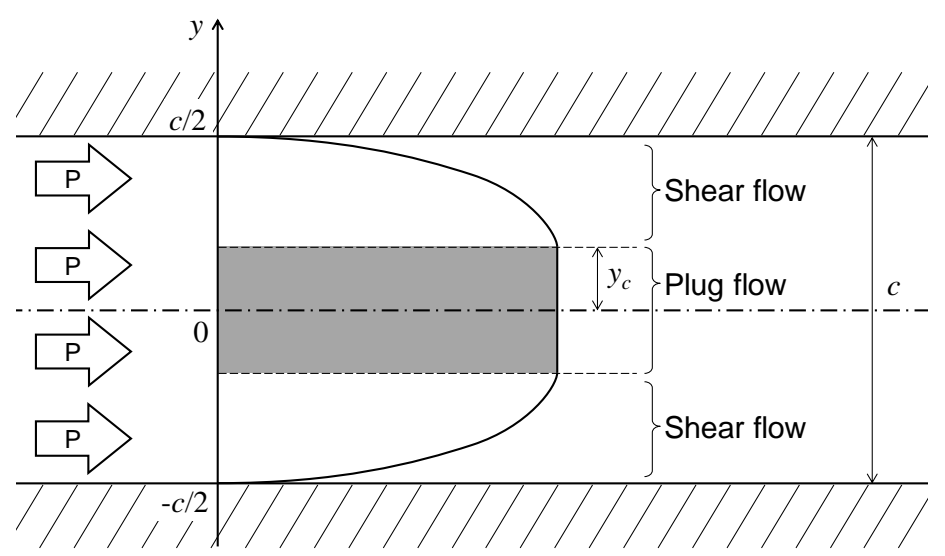

Fig. 6 Schematic diagram of grease flow in parallel plate. 


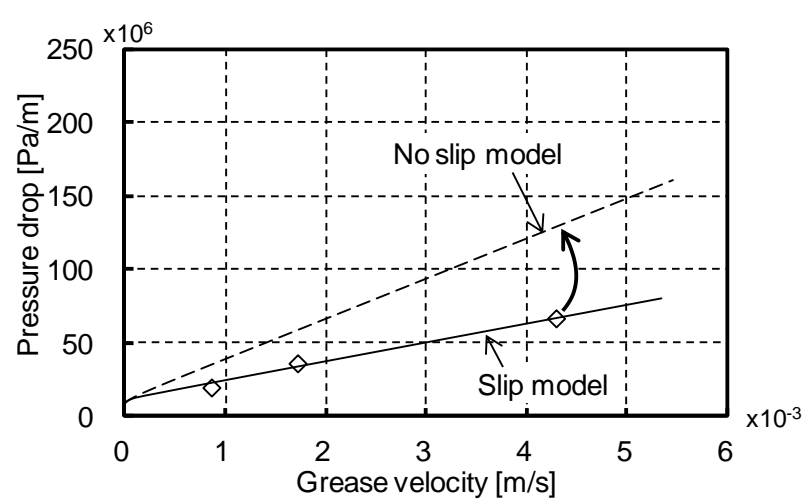

(a) Grease A

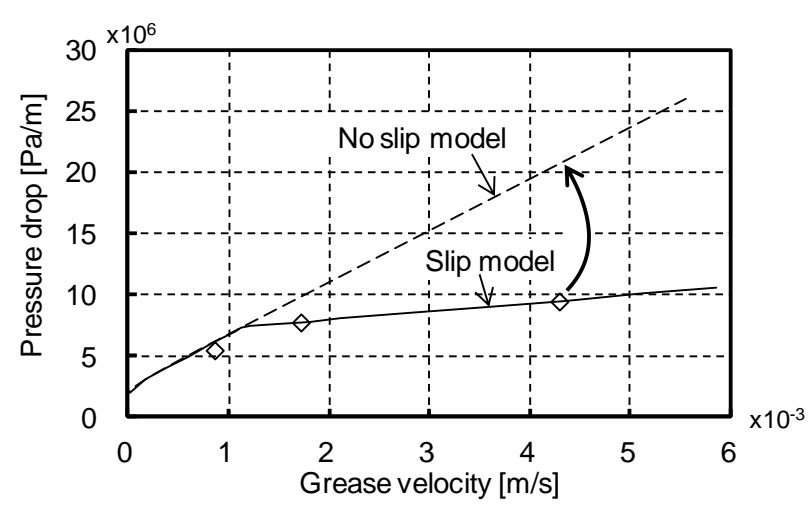

(c) Grease C

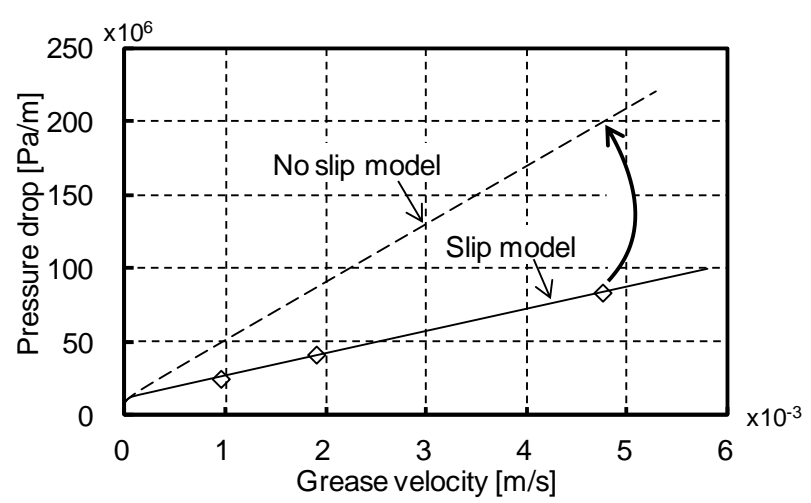

(b) Grease B

Fig. 7 The experimental results and calculated results of pressure drop. The theoretical results by no slip model are greater than the experimental results. The theoretical results by slip model are in good agreement with the experimental results.

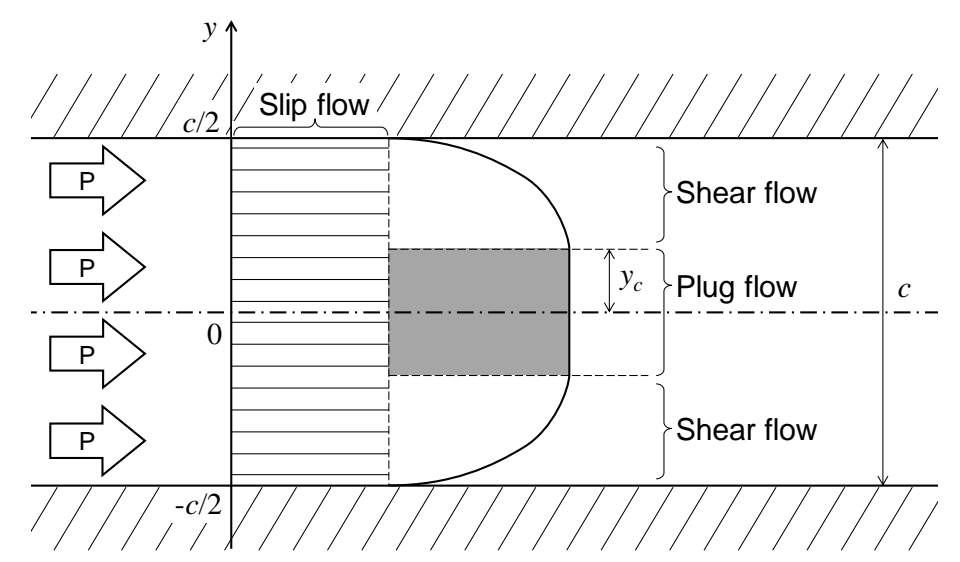

Fig. 8 Schematic diagram of grease flow with slip.

図 8 に，壁面での滑りを考慮した圧力損失モデルを図示する．滑りを伴って流れるとき，壁面で滑り抵抗が生 じる．熱伝導グリースと同様に，ビンガム流体としてモデル化されるフレッシュコンクリートでは，滑り抵抗が 滑り速度に比例するモデルが検討されており（鈴木他，2004），本論においても同様のモデル化を適用すると，滑 り抵抗 $\tau_{s l}[\mathrm{~Pa}]$ は以下の式で表される.

$$
\tau_{s l}=\eta_{s l} u_{s l}+\tau_{a}
$$


ここで， $\eta_{s l}$ は滑り摩擦係数 $[\mathrm{Pa} \cdot \mathrm{s} / \mathrm{m}], u_{s l}$ は滑り速度 $[\mathrm{m} / \mathrm{s}], \tau_{a}$ は付着力[Pa]である.このとき，滑りを伴う熱伝導グ リースの平均流速 $\bar{u}_{d f+s l}[\mathrm{~m} / \mathrm{s}]$ は, 以下の式で表される.

$$
\begin{aligned}
& \bar{u}_{d f+s l}=\bar{u}_{d f}+u_{s l} \\
& u_{s l}=\frac{1}{\eta_{s l}}\left(\frac{c \Delta p}{2}-\tau_{a}\right)
\end{aligned}
$$

前述した図 7 に，式（8）による滑りを考慮した圧力損失の理論值を実線で示す．なお，計算に用いた付着力と 滑り粘性係数は, 圧力損失の理論值と実測值との差を小さくするように, 最小二乗法を用いて求めた. 表 3 に, 求めた付着力と滑り粘性係数を示寸. 図のように, 滑りなしの条件のモデルで実測值との乘離が大きかった圧力 損失が大きな条件において，壁面での滑りを考慮した圧力損失モデルによる理論值は実測值とよい一致を示して いる．このように，壁面での滑りを考慮することで熱伝導グリースの圧力損失挙動を説明できることが確認でき た.

Table 3 Material constants of the greases.

\begin{tabular}{c|c|c|c|c}
\hline Grease & $\tau_{y}[\mathrm{~Pa}]$ & $\mu_{B}[\mathrm{~Pa} \cdot \mathrm{s}]$ & $\tau_{a}[\mathrm{~Pa}]$ & $\eta_{s l}[\mathrm{~Pa} \cdot \mathrm{s} / \mathrm{m}]$ \\
\hline \hline Grease A & 808 & 113 & 1256 & $2.72 \times 10^{6}$ \\
\hline Grease B & 490 & 130 & 1158 & $2.49 \times 10^{6}$ \\
\hline Grease C & 187 & 17.5 & 821 & $8.80 \times 10^{4}$ \\
\hline
\end{tabular}

\section{5. 伝熱性能の予測方法}

\section{$5 \cdot 1$ 熱コネクタの伝熱モデル}

図 9 に，熱コネクタの伝熱部の模式図を示す．熱コネクタでは，プラグ表面からソケット内表面へ熱伝導グリ 一スの伝導によって熱を伝える. 隙間距離 $c$ が周方向に均一であり, 隙間内に熱伝導グリースが完全に充填され ている場合，熱コネクタの熱コンダクタンス $C_{t}[\mathrm{~W} / \mathrm{K}]$ は以下の式で表わされる.

$$
C_{t}=\frac{\pi d_{p} L_{h t} \lambda_{g}}{c}
$$

ここで， $d_{p}$ はプラグの直径 $[\mathrm{m}], L_{h t}$ は伝熱部の長さ $[\mathrm{m}], \lambda_{g}$ は熱伝導グリースの熱伝導率 $[\mathrm{W} /(\mathrm{m} \cdot \mathrm{K})]$ あ゙る.

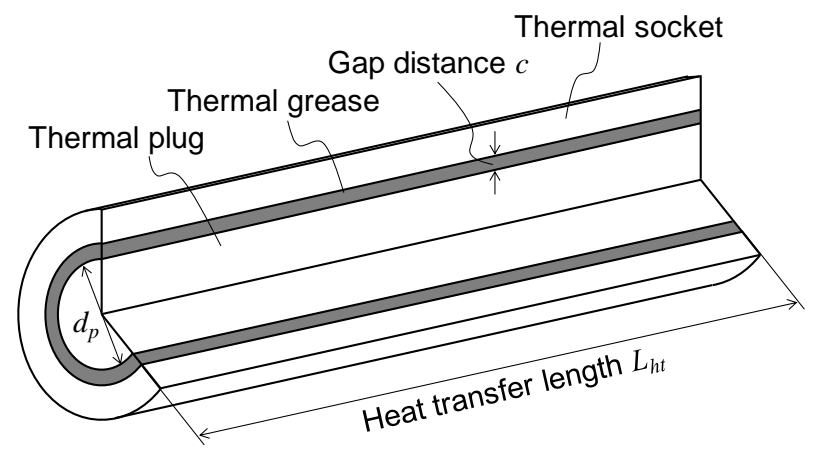

Fig. 9 Schematic diagram of heat transfer part of the thermal connector. 
式（10）は，隙間距離が周方向に均一である場合の理論式であるが，熱コネクタの伝熱性能のロバスト性を確 認するために，図 10 のように，プラグがソケットに対して偏心 $\delta[\mathrm{m}]$ をもって挿入される場合の熱コンダクタン スを考える．プラグとソケットの表面温度が周方向にそれぞれ均一であることを仮定すると，偏心がある場合の 熱コンダクタンスは以下の式で計算できる.

$$
C_{t}=L_{h t} \lambda_{g} \int_{0}^{2 \pi} \frac{d_{p}}{2 c} d \theta
$$

図 10 の角度 $\theta[\mathrm{rad}]$ の位置での隙間距離 $c$ は, 偏心 $\delta$ がソケットの直径 $d_{s}[\mathrm{~m}]$ に比べて十分小さいことを考慮する と, 以下の式で計算できる.

$$
c=\frac{d_{s}-d_{p}}{2}-\delta \cos \theta
$$

ここで，偏心がないときの熱コンダクタンスを $C_{t 0}[\mathrm{~W} / \mathrm{K}]$ とし，式（13）で定義する補正係数 $\gamma[-]$ 導入すると, 式（11）と式（12）より，式（14）が得られる.

$$
\begin{aligned}
& C_{t}=\gamma C_{t 0} \\
& \gamma=\frac{1}{\pi} \int_{0}^{\pi} \frac{1}{1-\delta^{*} \cos \theta} d \theta
\end{aligned}
$$

ただし， $\delta^{*}[-]$ は，以下の式で定義する無次元偏心量である. 無次元偏心量はプラグとソケットの隙間の平均距離 によって規格化した無次元量であり, 0 以上 1 未満である.

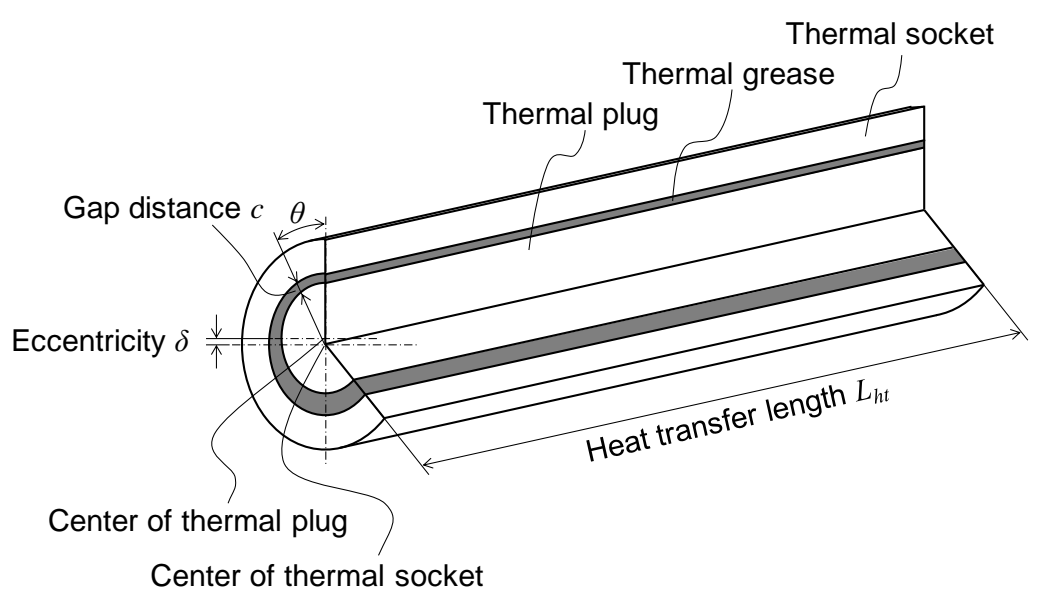

Fig. 10 Schematic diagram of heat transfer part of the thermal connector with eccentricity between the thermal plug and the thermal socket. 


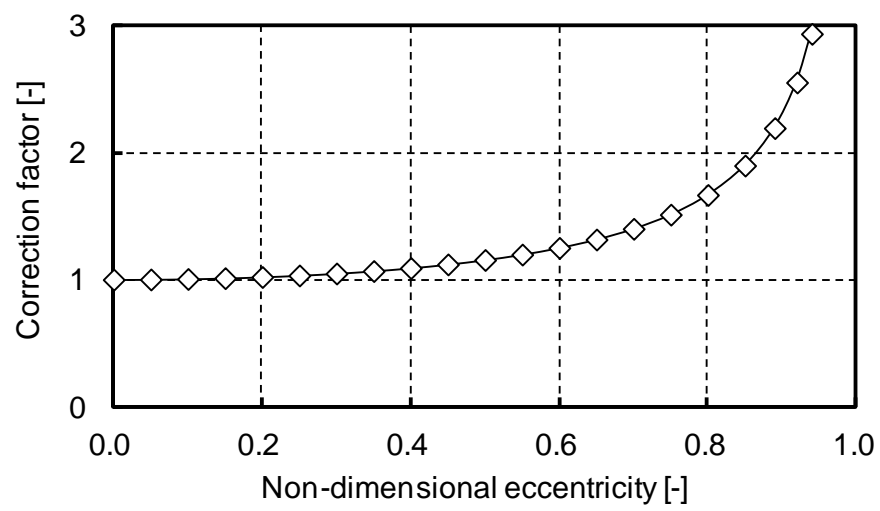

Fig. 11 The correction factor for thermal conductance of the thermal connector with eccentricity. The correction factor is always greater than one. This means that the thermal conductance of the thermal connector with no eccentricity is lower than that with eccentricity.

$$
\delta^{*}=\frac{2 \delta}{d_{s}-d_{p}}
$$

図 11 に式（14）により計算した，無次元偏心量 $\delta^{*}$ と補正係数 $\gamma$ の関係を示す. 図のように，補正係数 $\gamma$ は常 に 1 以上の值となる，つまり，偏心がある場合は偏心がない場合に比べて，熱コンダクタンスが常に高くなる. これは，偏心がある場合には，熱伝導グリース層が薄い部分で熱伝導が促進されていることに起因している。こ の結果から, 熱コネクタを設計する際には, 式（10）で示した偏心がない場合の熱コンダクタンスを計算するこ とで，偏心がある場合であっても熱コンダクタンスを過大に評価することがない.

\section{$5 \cdot 2$ 熱コンダクタンス測定実験}

\section{$5 \cdot 2 \cdot 1$ 実験装置および実験方法}

図 12 に，熱コンダクタンス測定装置の模式図を示す．本実験装置は，プラグ，コネクタ，熱伝導グリースを充 填するためのピストンにより構成した，プラグは，銅パイプの内部に発熱のためのカートリッジヒータを内蔵し て製作した．ソケットは銅製で，概略円筒形状であり，グリース溜めを設けた．プラグとソケットの表面に微小 な穴を開けて熱電対を埋設した。供試グリースには，前章で示したグリース A， B を使用した。供試グリースの 熱伝導率を定常法で測定した結果を表 4 に示す.

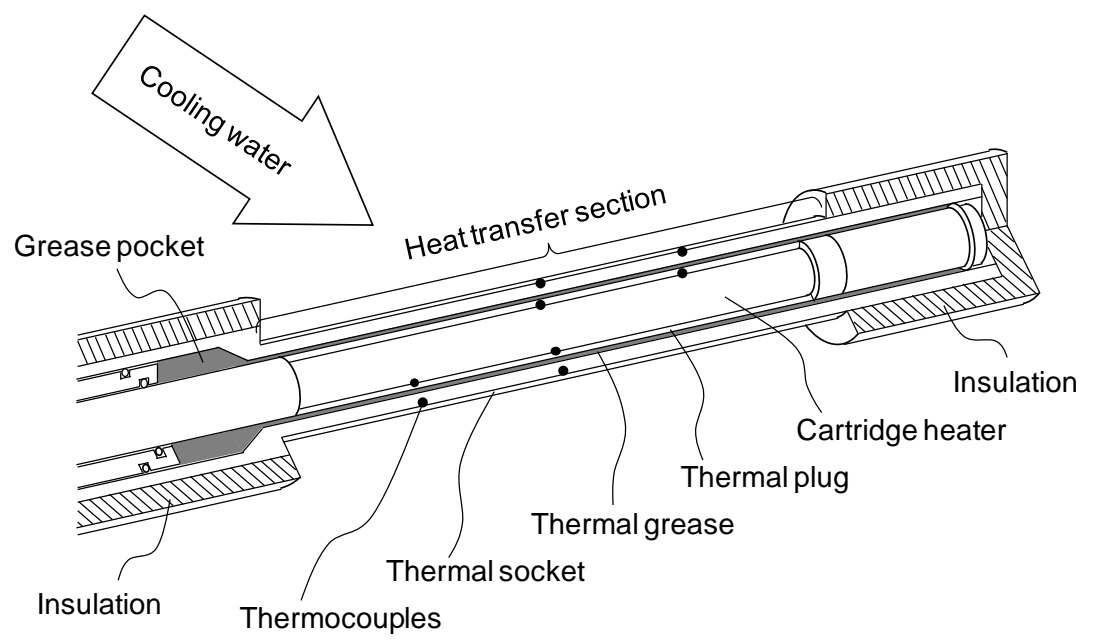

Fig. 12 Experimental apparatus for thermal conductance measurement. 
Table 4 Thermal conductivity of the specimen greases.

\begin{tabular}{c|c}
\hline Grease & Thermal conductivity $[\mathrm{W} /(\mathrm{m} \cdot \mathrm{K})]$ \\
\hline \hline Grease A & 4.04 \\
\hline Grease B & 2.71 \\
\hline
\end{tabular}

実験では，まず，プラグをソケットに挿入し，約 $20 〜 30{ }^{\circ} \mathrm{C} の$ 室温環境にて，平均流速 $1 \mathrm{~mm} / \mathrm{s}$ 程度でグリース をプラグとソケットの隙間に充填する. その後, プラグ内のカートリッジヒータを所定の熱量 $Q[\mathrm{~W}]$ で発熱させ, 実験装置全体を所定の温度に設定した冷却水槽に浸漬して, 受熱部の外周を冷却水で泠却し, 定常となったとき のプラグとソケットの温度を測定した．プラグの表面温度 $T_{p}\left[{ }^{\circ} \mathrm{C}\right]$ とソケットの表面温度 $T_{s}\left[{ }^{\circ} \mathrm{C}\right]$ から，下式を用い て熱コンダクタンス $C_{t}$ を算出した。

$$
C_{t}=\frac{Q}{T_{p}-T_{s}}
$$

温度測定完了後，プラグをソケットから抜き取る．本実験では，「挿入〜熱コンダクタンス測定〜抜き取り」を 1 サイクルとして，20サイクルの実験を実施した。このサイクル回数は，本熱コネクタを使用するブレードサーバ が製品寿命内に筐体に挿入される想定回数の 2 倍として決定した.

\section{$5 \cdot 2 \cdot 2$ 熱コンダクタンス測定結果}

図 13 に，熱コネクタの挿入回数ごとの熱コンダクタンスの測定結果を示す. 図中の〉印のプロットは測定值,

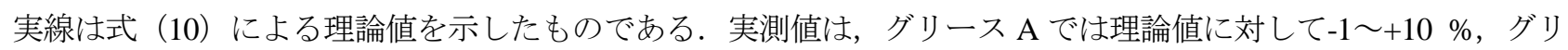
ース B では理論值に対して $\pm 0 \sim+26 \%$ となり，ほぼ全ての実測值が理論值より高い值となった. 実測值には測定 誤差によるばらつきも含まれているが，ほぼ全ての実測值が理論值よりも高くなっている原因の一つとして，5・ 1 節で述べた偏心の作用が考えられる. また，挿入回数が増えると熱コンダクタンスが低下寸る傾向は，確認さ れなかった。

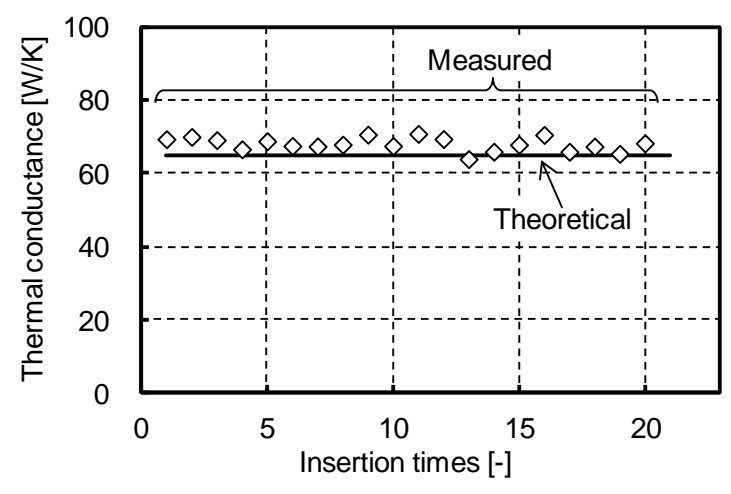

(a) Grease A

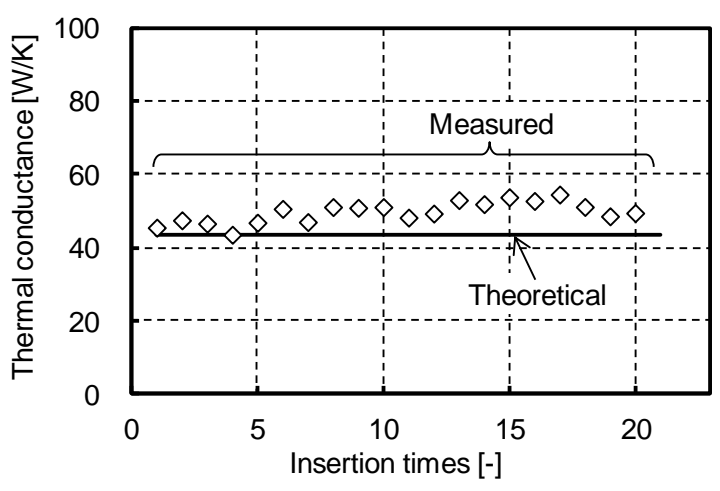

(b) Grease B

Fig. 13 Measurement results of the thermal conductance. 


\section{$5 \cdot 2 \cdot 3$ 熱伝導グリースの充填状況の可視化}

前項の抜き挿しを繰り返寸実験によって，熱コンダクタンスが低下しないことを確認したが，抜き挿しの際に 熱伝導グリース内に空気が混入した場合, 空隙が生じ, 熱コンダクタンスに影響を与える可能性があるため, 超 音波試験によって熱コネクタ内の熱伝導グリースの充填状態を可視化した.

図 14 に，可視化した画像を示す．図は，円筒状のグリース層部を周方向に展開した図であり，図の横方向が熱 コネクタの軸方向, 縦方向が熱コネクタの周方向に相当する. 色の濃淡はソケット内面での超音波の反射波の強 度を表わしており，反射波が弱い部分が黒く表示され，反射波が強い部分が白く表示される．空隙のある場所は ソケット内面での密度差が大きくなるため, 反射波の強度が強くなり, 白く表示される. 空隙以外の要因でも反 射波の強度が変わるため, 反射波の強度の絶対值で熱伝導グリースの有無は判断できないが, 周辺と比較してし っかりとした輪郭を持っている白い領域が，空隙のある部分であると考えられる．また，図中の黒い帯状の箇所 は，試験体の表面に貼付した熱電対の配線により測定ができない部分である.

図 14 (a) は 1 回目の挿入時の可視化結果であるが，数ヶ所に細かな空隙が確認できる. 図 14 (b) は 10 回目 の挿入時の可視化結果であるが， 1 回目の挿入時に確認されたような細かな空隙の他に，長手方向 $90 \mathrm{~mm}$, 角度 $90^{\circ}$ の辺りに，比較的大きな空隙が確認できる. 図 14 (c) は20回目の挿入時の可視化結果であるが, 長手方向 0〜20 mm, 角度 90〜270 の辺りにクラスタ状の細かな空隙が確認でき, また, 10 回目の挿入時に確認された比 較的大きな空隙が成長してさらに大きくなったものと思われる空隙が確認できる.

このように，抜き差しを繰り返すことで熱伝導グリース内に空隙が生じていくことが確認された，一方，熱伝 導グリース全体の伝熱面積に対する空隙の面積の割合は, 20 回目の挿入時であっても $4 \%$ 程度であり, 熱コンダ クタンスーの影響は大きくない. そのため, 前項の熱コンダクタンスの測定結果では, 挿入回数が増えることで の熱コンダクタンスの低下が確認されなかったものと考えることができる.

\section{6. 結 言}

プラグとソケットの隙間に熱伝導グリースを充填することで両者を熱的に接続する方式の熱コネクタに関して, 熱コネクタを設計する際に必要となるグリース充填力と伝熱性能の予測手法を検討し, 以下の結論を得た.

（1）熱伝導グリースの流動特性の測定結果を元に, ビンガム流体と仮定して流動特性を定式化し, 壁面での滑 りを考慮した圧力損失の理論值は，実測值と良好に一致した。この結果から，圧力損失の理論值を用いて グリース充填力を予測できることを確認した.

(2) 熱コンダクタンス測定実験の結果， 1〜20 回挿入時の実測值は理論值に対して $-1 〜+26 \%$ なった. 実測值 が理論值よりも高くなった原因の一つとして, プラグとソケットの偏心によって生じる, 熱伝導グリース 層の薄い部分での熱伝導の促進作用が考えられる，この結果から，理論值が熱コンダクタンスを過大に評 価しないことを確認した.

(3) 抜き差しを繰り返した試験の結果, 挿入回数を増やすことで熱コンダクタンスが低下する傾向は確認され なかった．また，熱伝導グリースの充填状況を超音波試験によって可視化した結果，20回挿入時での空隙 の割合は伝熱面積全体の $4 \%$ 程度であり, 本実験の条件下では, 発生した空隙が伝熱性能に及ぼす影響が 小さいことを確認した，この結果，実用上必要な回数の抜き差しに伴う気泡の混入を考慮しても，熱コネ クタの伝熱性能が問題ないことを確認した. 


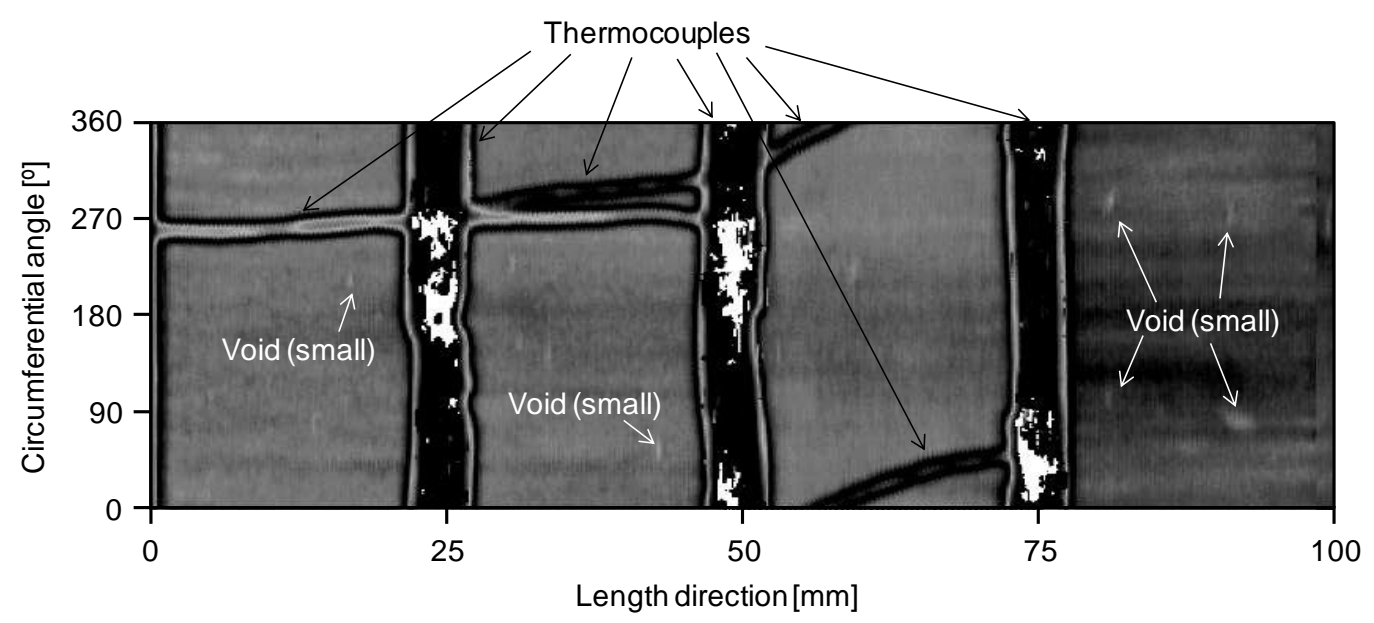

(a) After first insertion. There are some small voids.

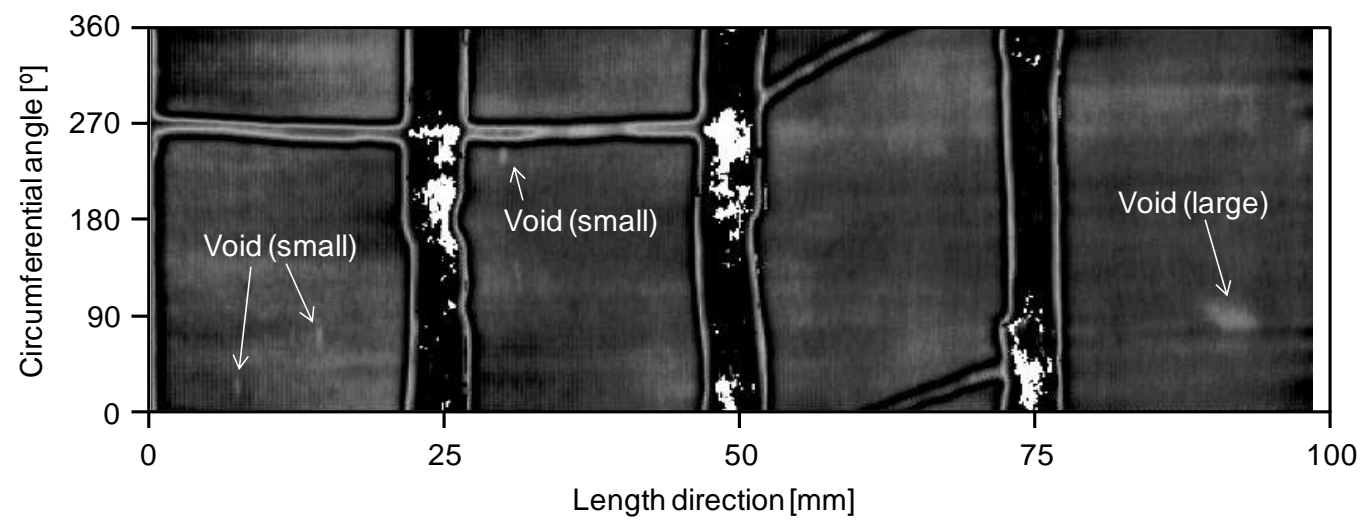

(b) After 10 insertions. There are some voids.

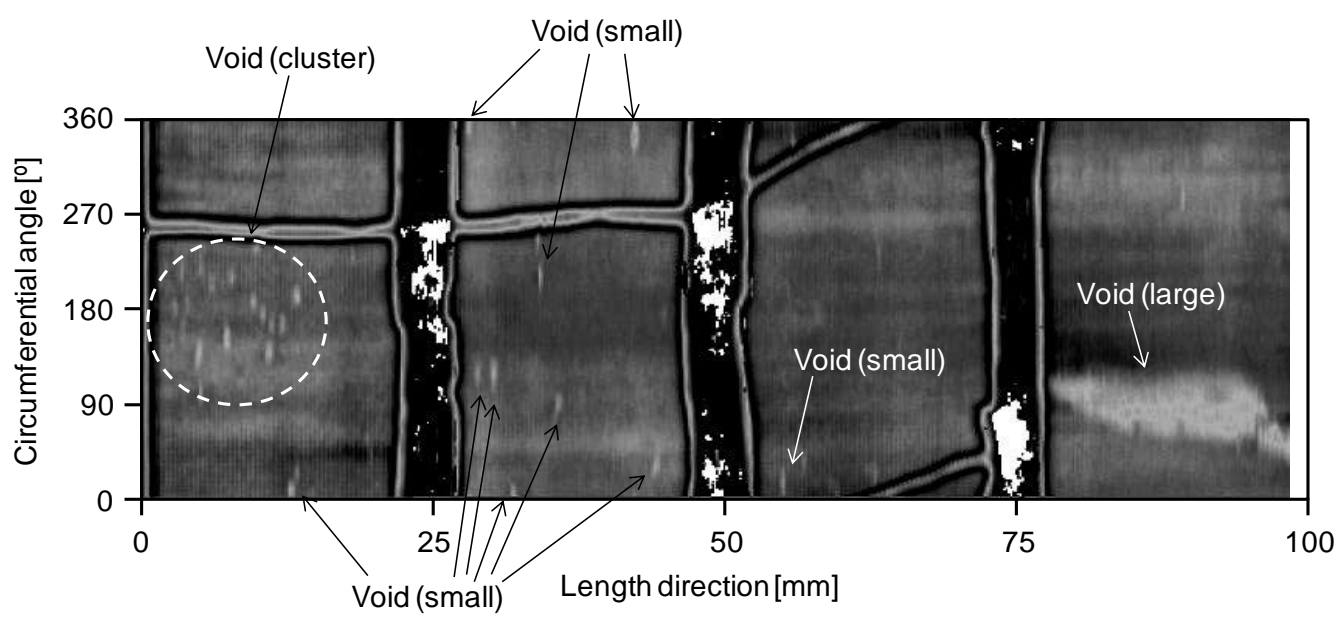

(c) After 20 insertions. Even there are some small voids and a large void, the percentage of the void area to heat transfer area is only $4 \%$. Then, the voids make the thermal conductance a little decrease.

Fig. 14 Grease distribution in the gap between the thermal plug and the thermal socket by ultrasonic testing. (Grease B) 


\section{文献}

新隆之, 大橋繁男, 鈴木敦, ブレードサーバ用液冷システムの検討, 熱工学コンファレンス講演論文集 (2004), pp.361-362.

藤本貴行, 武田文夫, 近藤義広, 藤居達郎, 加藤猛, 沸騰冷却を用いた高密度実装 ICT ラック用冷却装置（低背型 熱サイフォンの基本性能評価），日本機械学会論文集, Vol. 80, No. 815 (2014), DOI: 10.1299/transjsme.2014tep 0202.

藤本慶久, 半導体用熱伝導グリースのポンピングアウト挙動に及ぼす負荷条件の影響, 第 21 回機械材料・材料加 工技術講演会講演論文集 (2013), 302 .

林知生, 中島忠克, 近藤義広, 豊田浩之, 出居昭男, 椿繁裕, 電子装置とそれに用いるサーマルコネクタ, 特開 2010-80506 (2010).

近藤義広, 取り外し可能な熱コネクタの伝熱性能に関する要素検討, 日本伝熱シンポジウム講演論文集 (2010), p.357.

實方淳, 谷光清, 西隆之, 前川均, 辻岡重夫, SI-LCA による ICT 環境負荷評価:サーバのブレード化に関する評価, 第 3 回日本 LCA 学界研究発表講演要旨集 (2008), pp.156-157.

グリーン IT 推進協議会 調査分析委員会, 2008 年度 2012 年度 グリーン IT 推進協議会 調査分析委員会 総合報 告書 (2013), pp.58-61.

鈴木一雄, 越川茂雄, 伊藤康司, コンクリートの管内流動に関する研究, コンクリート工学論文集, Vol.15, No.2 (2004), pp.47-57.

日本機械学会編, 技術資料 管路・ダクトの流体抵抗 (1979), p.159.

山田邦弘, 磯部憲一, 高橋孝行, 放熱用シリコーングリース組成物及びそれを使用した半導体装置, 特開 2000-109373 (2000).

\section{References}

Atarashi, T., Ohashi, S. and Suzuki, O., Study on liquid cooling system for blade server, Proceedings of Thermal Engineering Conference (2004), pp.361-362 (in Japanese).

Fujimoto, T., Takeda, F., Kondo, Y., Fujii, T. and Kato, T., Cooling unit for high-density packaging ICT rack by using boiling heat transfer (Evaluation on basic cooling performance of low height type thermosyphon), Transactions of the JSME (in Japanese), Vol. 80, No. 815 (2014), DOI: 10.1299/transjsme.2014tep0202.

Fujimoto, Y., Effect of load conditions on the pumping out behavior of thermal grease for semiconductor, Proceedings of the 21st materials and processing conference (2013), 302 (in Japanese).

Hayashi, T., Nakajima, T., Kondo, Y., Toyoda, H., Idei, A. and Tsubaki, S., Electronic device and a thermal connector used therein, Japanese patent disclosure 2010-80506 (2010).

Kondo, Y., Basic study on heat transfer performance of removable thermal connector, Proceedings of the 48th National Heat Transfer Symposium of Japan (2010), p.357 (in Japanese).

Sanekata, J., Tani, M., Nishi, T., Maekawa, H. and Tsujioka, S., ICT environmental impact evaluation with SI-LCA:A case example of adoption of blade servers, The 3rd Meeting of the Institute of Life Cycle Assessment, Japan (2008), pp.156-157 (in Japanese).

Survey and Estimation Committee, Green IT Promotion Council, Survey and Estimation Committee General Report FY2008 to FY2012 (2013), pp.58-61 (in Japanese).

Suzuki, K., Koshikawa, S. and Itoh, Y., Studies on pipe flow of concrete, Vol. 15, No. 2 (2004), pp.47-57 (in Japanese).

The Japan Society of Mechanical Engineers, Hydraulic losses in pipes and ducts (1979), p.159 (in Japanese).

Yamada, K., Isobe, K. and Takahashi, T., Heat release silicone grease composition and semiconductor device using that Japanese patent disclosure 2000-109373 (2000). 